\title{
Health Information and Advertising Appeals in Food Commercials: A Content Analysis
}

\author{
Kara Chan*, Vivienne Leung and Lennon Tsang
}

Department of Communication Studies, Hong Kong Baptist University, Hong Kong

\begin{abstract}
A content analysis of 311 food commercials broadcast on television networks in Hong Kong was conducted. There were nearly equal proportions of ads for healthy and unhealthy foods. The three most frequently used advertising appeals were taste/flavor/smell/texture, health/wellbeing and physical performance/speed/strength. Altogether 54 percent of the food ads contained health-related claims. Intriguingly, 23 percent of the ads for unhealthy food contained health-related claims. The prevalent use of general health claims in unhealthy food ads calls for policy makers to devise better ways to regulate health claims in food advertisements. This is the first content analysis of health and nutrition information in food advertising arising from a society with a rich herbalist tradition.
\end{abstract}

Keywords: Children, Television, Nutrition, Diet, Healthy Eating.

\section{INTRODUCTION}

Television is a major socializing agent for children and youths about food, nutrition and health [1]. Food advertisements have significant influence on knowledge, attitudes, and behaviors about dietary choices. They can educate consumers about the nutrient content and health implications of foods and they have the potential to promote healthy foods and lifestyles [2]. Food advertisements are worth examining because of their potential association with obesity [3]. A review of content analysis studies on food advertisements found that unhealthy food categories such as ready-made breakfast cereals and low-nutrient beverages dominated the prime-time as well as children's television programs. The advertisements for unhealthy food items often adopted emotional appeals that focused on fun, mood alteration, and taste. Because of the vast number of adults and children watching television, it is important that nutrition educators learn what messages related to nutrition and health are presented in the media [4]. The current study conducted in Hong Kong provides empirical evidence about the health and nutrition information communicated to consumers through television advertisements. Results of the study can provide guidelines for policy-makers and health educators for decision making about the regulation of food advertising and the design of messages to counteract advertising effects.

\section{LITERATURE REVIEW}

Food advertising has the potential to influence food consumption and establish social norms related to

*Address correspondence to this author at the Department of Communication Studies, Hong Kong Baptist University, Kowloon Tong, Hong Kong; Tel: (852) 3411 7836; Fax: (852) 3411 7890; E-mail: karachan@hkbu.edu.hk eating [5]. Televised food advertisements encouraging specific food products form a de facto set of dietary endorsements [6]. As a result, there is much attention given to the study of nutrition information, persuasive appeals, and profiles of food advertising. Food advertising on television was frequently studied because of the demonstrative power of television, the huge size of the audience, and the potential to have impact on the child segment.

This section reviews previous studies on content analysis of food advertising on television. We first review content analysis studies of television programs for adults and children, then studies of television programs primarily for children. Content analysis of food advertisements in the print media are not included. It follows with a brief introduction of food advertising and its regulation in Hong Kong.

In a longitudinal study of prime-time television food advertising from 1971 to 1998 in the US, it was found that the "prime-time diet" was composed of mostly low nutrient density foods such as fast-food fare, low nutrient beverages, as well as sweets and desserts. Over 85 percent of food commericals adopted consumer-related promotional claims, such as those emphasing flavor, quality, and value-for-money. Less than 45 percent of food commercials adopted nutritionrelated claims. A content analysis of US Saturday morning programs in 2004 found that the food advertised failed to meet nutrition guidelines and encouraged nutritional imbalance. The food diet on TV recommended 25 times the recommended daily servings for sugars, and 21 times the recommended daily servings for fat. The same food diet on TV also recommended only 40 percent, 32 percent, and 27 percent of the recommended daily servings for 
vegetables, diary, and fruits respectively [6]. A content analysis comparing types of health and nutrient content claims in prime-time Spanish and English-language television advertisements that targeted women aged 18 to 35 years in US found that food advertisements broadcast in Spanish-language television contained significantly more nutrition information and "good for health" claims than those broadcast in Englishlanguage television [7].

Another study compared food advertisements in prime-time television for the general market and for the African American television programs [8]. It was found that food advertisements broadcast during African American programs contained a higher proportion of advertisements for fast food, candy, or soda. Food advertisements broadcast during general market programs contained a higher proportion of advertisements for cereals, grains and pasta, as well as fruits and vegatables. About one-sixth of all sampled commercials contained a weight-related nutritional claim [8]. A recent study of 93,284 food advertisements aired on Australian television found that 16 percent of the sampled advetisements contained negative themes. The most frequently adopted negative themes were mood enhancement and food craving. Advertisements with negative themes appeared most frequently for non-core foods as well as being broadcast during children viewing times [5].

Given the powerful impact of television advertising on children's food attitudes, some of the content analysis studies focused on food advertisements broadcast during children's viewing hours. A study of 28 hours of US children television programs in 2005 found that the most frequently advertised food categories were breakfast cereal and cereal bars, restaurants, and snackfoods. Altogether, 91 percent of food advertisements were for foods or beverages high in fat, sodium, or added sugers, or low in nutrients. In terms of promotional strategy, 74 percent of the sampled ads featured cartoon characters, and 26 percent featured toys or other giveaways [9].

Similar results were found by a random sample of 1,130 advertisements appearing during children viewing hours in English- as well as Spanish-language networks in 2005 and 2006 [10]. Altogether, 70 percent of food ads were for food categories high in sugar or fat. Ads for fruits and vegetables comprised only 2 percent of the sample. Only one nutrition-related public service announcement was found for every 63 food ads [10]. Food televised advertising over children viewing hours in New Zealand also contained high percentages of food categories that were contrary to nutritional guidelines [11].

Moon (2010) [2] studied food advertising on television targeted at children in Korea. The results showed that these advertisements encouraged the consumption of unhealthy foods using sensory and emotional appeals such as taste, smell or mood alteration. Food advertisements seldom carried health information. Some ads put an emphasis on "health" without making explicit substantial claims on nutrition contents. Some presentations of health-related claims are misleading for a child audience [2]. Cheng and his colleagues conducted a content analysis of 1,355 Chinese and 1,711 American commercials broadcast during children's programs. The results revealed that emotional appeals occured more often than health- or nutrition-related appeals. This US sample of advertisements had a higher percentage of highcalorie/high-sugar foods than the Chinese sample [12].

Food advertisements targeted at children, put much emphasis on emotional persuasive appeals [2, 3, 13]. Among the persuasive cues, immediate sensory gratification (e.g., fun, hedonic cues; giveaways) and attention-getting devices such as animation, live-action visual effects as well as sound effects were frequently employed [14-17]. Persuasive cues such as taste or smell, and emotional appeal such as mood alteration were found most frequently in food advertising targeted at children [13]. The most popular appeals used in food advertising were hedonistic, emphasizing taste, humor, fun and action-adventure [18]. The commonly assumed prevalence of calls to pester parents to make purchase, or celebrity endorsements were not supported. Sales promotions such as giveaways or competition prizes were frequently used to advertise cereals and fast food [18]. To conclude, food advertised on television were often not nutritious, and these advertisements often used emotional appeals to encourage consumption.

\section{Food Advertising and its Regulation in Hong Kong}

In Hong Kong, the food and beverages product category accounted for about 8 percent of total advertising spending in 2011. It was the second largest category after banking and investment services [19]. Among all types of food advertising, health supplements are heavily promoted. This is because in Chinese culture, the efficacy of a macrobiotic diet is based on the principle of "Yin" and "Yang" balance [20]. Intake of various tonics and supplements is believed to 
be able to raise the flow of energy in the body and maintain body homeostasis [21]. In a survey about health supplement consumption in Hong Kong, over one third of adult respondents had consumed health supplement products within the previous six months [22].

Advertising claims relating to nutrition or the dietary effects of products or services are subject to government regulation. Advertisements for dietary supplements must not state or imply that are necessary as additions to a balanced diet [23]. According to a compulsory nutrition labeling scheme for food introduced in July 2010, all prepackaged foods and beverages sold in Hong Kong must be labeled with their energy value, protein content, available carbohydrates, total fat, saturated fatty acids, sodium, sugar, and the content of any other nutrients [24].

In view of the importance of food advertising to public health and the power of the television medium, there is a need to study the health information contained in televised food advertisements. This study addressed four research questions.

RQ1: What is the proportion of healthy and unhealthy food advertised on television in Hong Kong?

RQ2: What types of persuasive appeals are employed in television food advertisements?

RQ3: What types of health-related claims are made in television food advertisements? Specifically, how frequently are claims about Chinese herbal substance made in these advertisements?

RQ4: How are health-related claims presented in television food advertisements?

\section{METHODOLOGY}

\section{Sample}

The sample of ads was collected from an online archive of advertisements provided by the admanGo company. It covered two specific time frames: October to November, 2010 and April to May, 2011. These four months were selected to reflect seasonal variations in food advertisements. The four product categories examined were food, beverages and restaurants; pharmaceuticals and healthcare; beauty products; and hotels and entertainment. Only advertisements for edible products were studied. Advertisements for medications were excluded. Duplicated commercials were included only once to eliminate bias from the broadcast frequency of commercials. A total of 311 commercials were downloaded and analyzed. All the ads lasted from 5 to 60 seconds.

The sample for this study included only advertisements broadcast on paid or free-to-air local television channels. Global television channels such as Discovery channels were not included. Television was chosen because television accounted for the highest share (35 percent) of total advertising expenditure among all media in Hong Kong [25]. Using one singlemedium is justified as this is an exploratory study. Future study will examine and compare other media such as newspapers and magazines.

\section{Coding}

The coding frame (see Table 1) was adopted from Moon's (2010) [2] study. It included 11 product categories, 18 persuasive appeals, 5 general health claims, 15 nutrition/substance claims, and 3 types of nutrition/substance claims. Following the coding method suggested by Moon (2010) [2], the eleven product categories were classified as either healthy or unhealthy foods (see Table 2 for the classification). The "restaurant" category consisted mainly of fast food restaurants. It was classified as unhealthy food because none of the sampled advertisements put emphasis on serving healthy foods. For advertisements with nutrition or substance claims, the types of claims and the manner of their audio-visual presentation were coded. A pilot sample of twenty commercials (10\%) was coded by all three authors and a research assistant so that the coders became familiar with the coding frame. These ads were not included in the final sample. A graduate research assistant employed for the project and one of the authors coded all advertisements independently. The inter-coder reliability scores based on percentage of agreement ranged from 0.70 to 1.0 (see Table 1). All disagreements were resolved through discussion, and a final decision was made by consensus between the coders.

\section{FINDINGS}

\section{Product Types}

The sample contained almost equal proportions of ads for healthy and unhealthy food (see Table 2). This answers our first research question. Health supplements/water was the category most frequently 


\section{Table 1: Coding Frame and Inter-Coder Reliability}

Product categories (0.93)

Rice/grain/cereal/pasta, Meat/fish/poultry, Dairy, Fruit/vegetables/100\% juice, Health supplements/water, Family/fast food restaurants, Desserts/candies/sweets/snacks, Soft drinks/tea/coffee, Condiments, Convenience/pre-prepared food, Others

Target groups (0.93)

Children and youth, adults, both

Persuasive appeal (can code more than one appeal)

Product appeals

Competitive/unique: presented as better than or different from other brands (0.93)

Premium offers: product has associated free gifts or material benefits $(0.93)$

New (introduction of a new product or flavor) (0.97)

Quantity/size/amount: claims about the size or amount of the product (1.0)

Taste/flavor/smell/texture: description of the product's sensory characteristics $(0.82)$

Nutritional content: specific claims about fiber, fat, calories, sugar, protein, or carbohydrates; includes claims about product purity (e.g., $100 \%$ juice) or lack of additives (0.70)

Convenience: product is easy to prepare and/or consume (e.g., ready-to-eat or heat and eat) (0.86)

Value for money: claims of better product value for the money spent (e.g., buy one get one free, free $30 \%$ more) $(0.97)$

Emotional appeals

Mood alteration: suggests the product will either create or enhance positive feelings (e.g., happiness, relief) or remove negative feelings (e.g., anxiety, anger over not having the product) (0.93)

Health/well-being: product consumption is associated with a general improvement in overall health or well-being as well as claims about weight management or dieting $(0.74)$

Physical performance/speed/strength: product consumption will enhance physical performance or energy (e.g., sports performance, stamina) or will enhance the function of specific body parts $(0.70)$

Achievement/enablement: product consumption is linked with being able to obtain a desired goal or achieving control over undesirable aspects of the self or the environment $(0.82)$

Action/adventure: product is associated with engaging in daring activities, thrill-seeking (1.0)

Magic/fantasy: product is associated with producing effects by charms, spells, rituals, sleight of hand, or concealed apparatus (0.97)

Peer acceptance/superiority: product consumption is associated with peer acceptance or being better than one's peers (0.97)

Adult approval or disapproval: product consumption is linked to either adults' (or other authority figures') approval of the child, or getting away with something despite disapproval (0.93)

Appearance: improved appearance as the main reason for having the product $(0.97)$

Trickery/deceit: denying, tricking, or deceiving others out of the product $(0.97)$

Health-related claims (can code more than one type of claim)

General health claims: good for health, prevents illness, gives energy, provides balance/variety, fitness (0.86)

Nutrition/substance claims: Light (lighter)/lean (leaner)/diet, claims about fat, calories, protein, carbohydrate, fiber, sugar, caffeine, cholesterol, sodium, additive free, pure/natural, vitamin or minerals, calcium, other (0.79)

Type of nutrition/substance claims (1.0)

Absolute claim (e.g., "contains 500 milligrams of sodium")

Relative claim (e.g., includes not only disclosure of the nutrient level, but adds information on the recommended daily level and the percentage of that daily value for the nutrient)

Evaluative claim (e.g., specifies that the per serving level of the disclosed nutrient is 'high' based on some standard)

Audio/visual presentation (0.81)

Visual presentation only, Audio presentation only (or voice-over), both visual and audio

Text (0.78)

Present, not present

Spokesperson (0.97)

Present, not present

advertised, followed by family/fast food restaurants and desserts/candies/sweets. These three food categories accounted for 68 percent of all sampled advertisements.

\section{Appeals}

The three appeals used most frequently were taste/flavor/smell/texture, health/wellbeing and physical performance/speed/strength. The three appeals least used were peer acceptance/superiority, magic/fantasy and action/adventure (see Table 3). None of the advertisements used a trickery/deceit appeal. Chisquare tests showed that advertisements for healthy and unhealthy foods tended to adopt different persuasive appeals. The appeals used most frequently in ads for healthy food were health/wellbeing, physical performance/speed/strength, taste/flavor/smell/texture 
Table 2: Healthy and Unhealthy Food Classifications, and their Proportions in the Sample $(\mathrm{N}=311)$

\begin{tabular}{|c|l|}
\hline Product category & $\%(\mathbf{N})$ \\
\hline \hline Healthy food & $50.8(158)$ \\
\hline Health supplements/water & $35.7(111)$ \\
\hline Dairy & $8.4(26)$ \\
\hline Rice/grain/cereal/pasta & $3.2(10)$ \\
\hline Meat/fish/poultry & $2.2(7)$ \\
\hline Fruit/vegetables/100\% juice & $1.3(4)$ \\
\hline Unhealthy food & $49.2(153)$ \\
\hline Family/fast food restaurants & $19.3(60)$ \\
\hline Desserts/candies/sweets/snacks & $13.4(42)$ \\
\hline Soft drinks/tea/coffee & $9.9(31)$ \\
\hline Convenience/pre-prepared food & $4.1(13)$ \\
\hline Condiments & $2.2(7)$ \\
\hline Total & $100.0(311)$ \\
\hline
\end{tabular}

and nutritional content. Ads for unhealthy foods most often used taste/flavor/smell/texture, mood alteration, health/wellbeing and newness. Ads for unhealthy foods were also more likely to employ quantity/size/amount appeals. This suggests an answer to our research question 2.

\section{Health-Related Claims}

Of the 311 advertisements studied, 170 (54.7\%) contained a health-related claim. Altogether 84 percent of the ads for healthy foods and 23 percent of those for unhealthy foods contained health-related claims (see Table 4). This suggests an answer to the third research question. General health claims were used more often than nutrition/substance claims.

Altogether, $\quad 76 \quad$ commercials contained nutrition/substance claims that were classified as "others". The four commonly used Chinese herbs/substances, including Ophiocordyceps sinensis, Lingzhi mushrooms, bird's nest, and Ginseng, accounted for 31 out of the 76 mentions. Only commercials for healthy food contained nutrition claims of Chinese herbs/substances.

It was surprising to find that nearly one fourth of the ads for unhealthy foods made health-related claims. The health-related claim used most frequently in such ads was "good for health". Six out of the 23 chi-square tests were significant at 0.05 level, indicating that the types of health claims used in ads for healthy and unhealthy foods were similar.

Of the 123 advertisements with nutrition/substance claims, only six made an "absolute claim" and one

Table 3: Persuasive Appeals $(\mathrm{N}=311)$

\begin{tabular}{|c|c|c|c|c|}
\hline Persuasive appeal & $\begin{array}{c}\mathbf{N}=311 \\
\%\end{array}$ & $\begin{array}{l}\text { Healthy food } \\
\qquad \begin{array}{c}N=158 \\
\%\end{array}\end{array}$ & $\begin{array}{l}\text { Unhealthy food } \\
\qquad \begin{array}{c}N=153 \\
\%\end{array}\end{array}$ & Chi-square value \\
\hline Taste/flavor/smell/texture & $45.3(141)$ & 25.9 & 65.4 & $48.7^{\star *}$ \\
\hline Health/well-being & $35.0(109)$ & 55.7 & 13.7 & $60.1^{* *}$ \\
\hline Physical performance/speed/strength & $25.7(80)$ & 45.6 & 5.2 & $66.2^{* *}$ \\
\hline Nutritional content & $15.8(49)$ & 22.2 & 9.2 & $9.9^{* *}$ \\
\hline Mood alterations & $16.1(50)$ & 7.6 & 24.8 & $17.1^{* *}$ \\
\hline Convenience & $14.5(45)$ & 15.8 & 13.1 & 0.5 \\
\hline New & $10.0(31)$ & 6.3 & 13.5 & $4.7^{*}$ \\
\hline Value for money & $8.4(26)$ & 6.3 & 10.5 & 1.7 \\
\hline Premium/offers & $5.5(17)$ & 3.1 & 7.7 & 3.2 \\
\hline Competitive/unique & $5.8(18)$ & 7.5 & 3.9 & 2.0 \\
\hline Achievement/enablement & $4.8(15)$ & 7.0 & 2.6 & 3.2 \\
\hline Appearance & $4.8(15)$ & 6.3 & 3.3 & 1.6 \\
\hline Adult approval or disapproval & $4.8(15)$ & 5.1 & 4.6 & 0.0 \\
\hline Quantity/size/amount & $4.2(13)$ & 1.9 & 6.5 & $4.1^{*}$ \\
\hline Peer acceptance/superiority & $2.6(8)$ & 2.5 & 2.6 & 0.0 \\
\hline Magic/fantasy & $1.0(3)$ & 1.3 & 0.7 & 0.3 \\
\hline Action/adventure & $2.3(7)$ & 0.0 & 4.6 & 7.4 \\
\hline Trickery/deceit & $0.0(0)$ & 0.0 & 0.0 & N.A. \\
\hline
\end{tabular}

*Indicates significance at the $p \leq 0.05\left({ }^{* *} p \leq 0.01\right)$ level of confidence. Each commercial can have more than one persuasive appeal. 
Table 4: Health-Related Claims $(\mathrm{N}=170)$

\begin{tabular}{|c|c|c|c|c|}
\hline Health-related claims & $\begin{array}{c}N=170 \\
\%(n)\end{array}$ & $\begin{array}{l}\text { Healthy food } \\
\qquad \begin{array}{c}N=134 \\
\%\end{array}\end{array}$ & $\begin{array}{l}\text { Unhealthy food } \\
\qquad \begin{array}{c}\mathbf{N}=36 \\
\%\end{array}\end{array}$ & Chi-square value \\
\hline General health claim & $95.9(163)$ & 97.0 & 91.7 & 2.1 \\
\hline Good for health & $70.6(120)$ & 72.4 & 63.9 & 1.0 \\
\hline Prevents illness & $13.5(23)$ & 14.9 & 8.3 & 1.1 \\
\hline Fitness & $12.9(22)$ & 14.2 & 8.3 & 0.9 \\
\hline Provides balance/variety & $4.7(8)$ & 5.2 & 2.8 & 0.4 \\
\hline Gives energy & $4.7(8)$ & 3.7 & 8.3 & 1.3 \\
\hline Nutrition/substance claim & $72.4(123)$ & 74.6 & 63.9 & 1.7 \\
\hline Vitamin/mineral & $19.4(33)$ & 20.9 & 13.9 & 0.9 \\
\hline Calcium & $8.8(15)$ & 11.2 & 0.0 & $4.4^{*}$ \\
\hline Fiber & $6.5(11)$ & 6.0 & 8.3 & 0.3 \\
\hline Pure/natural & $5.9(10)$ & 3.7 & 13.9 & $5.3^{*}$ \\
\hline Fat & $2.4(4)$ & 0.0 & 11.1 & $15.2^{* *}$ \\
\hline Sugar & $1.2(2)$ & 0.0 & 5.6 & $7.5^{*}$ \\
\hline Protein & $1.2(2)$ & 1.5 & 0.0 & 0.5 \\
\hline Sodium & $1.2(2)$ & 1.5 & 0.0 & 0.5 \\
\hline Calorie & $0.6(1)$ & 0.0 & 2.8 & 3.7 \\
\hline Cholesterol & $0.6(1)$ & 0.0 & 2.8 & 3.7 \\
\hline Light/lighter, Lean/leaner, Diet & $0.6(1)$ & 0.7 & 0.0 & 0.3 \\
\hline Carbohydrate & $0.0(0)$ & 0.0 & 0.0 & 0.0 \\
\hline Caffeine & $0.0(0)$ & 0.0 & 0.0 & 0.0 \\
\hline Additive free & $0.0(0)$ & 0.0 & 0.0 & 0.0 \\
\hline Others & $44.7(76)$ & 50.7 & 22.2 & $9.3^{* *}$ \\
\hline $\begin{array}{l}\text { Common Chinese } \\
\text { herbal/substance }\end{array}$ & $18.2(31)$ & 23.1 & 0.0 & $10.2^{\star \star}$ \\
\hline
\end{tabular}

*Indicates significance at the $p \leq 0.05\left({ }^{* *} p \leq 0.01\right)$ level of confidence.

${ }^{\dagger}$ Including Ophiocordyceps sinensis, Lingzhi mushrooms, bird's neat, and Ginseng. Each commercial can have more than one health-related claim.

made an "evaluative claim". None of them used a "relative claim". None of the other 117 advertisements contained specific information about the nutrition value of the constituents.

\section{The Presentation of Health-Related Claims}

About 89 percent of the health-related claims were presented both visually and orally in the same ad, five percent were presented with audio only (voice-over) and three percent were presented only visually. Healthrelated claims were also delivered in text $(68.2 \%)$ and by a spokesperson (28.2\%), including verbal endorsements from celebrity/authoritative endorsers. The figure for text presentation is probably specific to Hong Kong where Chinese subtitling is pervasive on television for audience who may not understand the Cantonese dialect.

\section{DISCUSSION}

Unlike studies in the US and Australia, the Hong Kong televised food advertisements contained a high proportion of healthy food categories. Over one-third of the sampled food advertisements were promoting healthy supplements and bottled water. The prevalence of health supplements indicates that the Hong Kong food market is adult oriented. Those adults are health conscious, and marketers are keen to encourage them to take health supplements to boost their health.

The appeals most frequently used in food TV advertising probably reflect marketers' perceptions of consumers' interests. The top three were taste, wellbeing, and physical performance. They reflect a mixture of both utilitarian and symbolic rewards expected from food consumption. Marketers try to make a clear distinction in user benefits between healthy and unhealthy food products. This is understandable, as marketers will try to emphasize each product's distinctive features. It is interesting that sensual satisfaction was the third most frequently used appeal in ads for healthy foods. This may reflect a worry among marketers that consumers may perceive healthy foods as not very tasty. A previous study of 
Hong Kong adolescents showed that in general they perceived healthy eating as beneficial and desirable, but boring and not enjoyable [26]. There is a Chinese saying that "A medicine may taste bad but be good for the health". In order not to associate healthy foods with medicine, food advertisers remind consumers that the healthy food advertised can satisfy their sensory needs.

The same thinking also applies to marketers of unhealthy foods. Over half of the sample of food ads was found to make at least one health-related claim. Over 60 percent of the ads for unhealthy foods with a health-related claim contained a general claim of being "good for health". This should alarm policy makers. Hong Kong's current advertising regulations have stringent restrictions on the use of claims regarding the nutritional value of food, and claims about the treatment effects of food products. However, there is no clear restriction in the current advertising regulations on making general health claims. In view of the prevalence of general health claims in food advertisements, it is time for the policy makers to revisit the issue and provide concrete guidelines about the use of general health claims. Evidence should be needed to justify such claims. And there is, an obligation to disclose related side-effects.

Chinese food culture places much emphasis on consuming food that matches the consumer's individual physique. However, none of the food advertisements in the sample provided information about the types of physique that the food product is most likely to benefit. This is probably because television is a mass medium and advertising on TV is very costly. Marketers therefore need to appeal to the largest number of potential consumers. The consumers may get the impression that the food advertised benefits all physiques. That may lead to a mismatch between the consumer and healthy foods.

The sample contained nearly equal number of ads claiming Chinese herbal ingredients as those claiming vitamin ingredients. That finding indicates that any revised regulations must cover claims about Chinese herbs in advertisements.

Only seven of the ads made absolute or evaluative claims. The scarce use of absolute or relative claims in food advertisements indicates that food advertisers do not think consumers are ready to receive such information. It may be perceived as too difficult for consumers to understand. Perhaps the food advertisers would prefer to remain vague about specific nutritional content. Without a benchmark, consumers can easily be misled by claims such as "less sugar". Policy makers should look into it, as most claims about nutrition and content are neither absolute nor benchmarked.

This content analysis study has two major limitations. First, content analysis is unable to generate information about the information processing of the ads by the audience. And second, the classification of healthy and unhealthy foods was based on broad food subcategories.

\section{CONCLUSION}

A content analysis of health information and advertising appeals used in television food advertisements was conducted. The food categories of health supplements/water, restaurants, and desserts/ candies/sweets accounted for over two-thirds of the sample. There were nearly equal proportion of ads for healthy and unhealthy food categories. Healthy food ads put an emphasis on the product's functional rewards while ads for unhealthy food emphasize emotional rewards for the consumers. Health claims are prevalent in health food ads, however a significant proportion of ads for unhealthy food also make healthrelated claims. The number of ads with specific claims about Chinese herbs was comparable to the number with specific claims about nutritive elements such as vitamins. The heavy use of general health claims indicates that there is a need for policy makers to set specific guidelines regulating them.

\section{ACKNOWLEDGEMENT}

This study was fully supported by Faculty Research Grant of Hong Kong Baptist University (Project no. FRG/10-11/211).

\section{REFERENCES}

[1] American Dietetic Association. Nutrition trends survey: Key findings. Chicago, IL: The American Dietetic Association 1997.

[2] Moon YS. How food ads communicate 'health' with children: A content analysis of Korean television commercials. Asian J Commun 2010; 20(4): 456-76. http://dx.doi.org/10.1080/01292986.2010.496858

[3] Kelly B, Halford JCG, Boyland EJ, Chapman K, BautistaCastano I, Berg C, et al. Television food advertising to children: A global perspective. Am J Public Health 2010; 100(9): 1730-36.

http://dx.doi.org/10.2105/AJPH.2009.179267 
[4] Byrd-Bredbenner C, Grasso D. Trends in US prime-time television food advertising across three decades. Nutr Food Sci 2000; 30(2): 59-66. http://dx.doi.org/10.1108/00346650010314278

[5] Pettigrew S, Roberts M, Chapman K, Quester P, Miller C. The use of negative themes in television food advertising. Appetite 2012; 58(2): 496-503.

http://dx.doi.org/10.1016/j.appet.2011.12.014

[6] Mink M, Evans A, Moore CG, Calderon KS, Deger S. Nutritional imbalance endorsed by televised food advertisements. J Am Diet Assoc 2010; 110(6): 904-10. http://dx.doi.org/10.1016/j.jada.2010.03.020

[7] Abbatangelo-Gray J, Byrd-Bredbenner C, Austin SB. Health and nutrient content claims in food advertisements on Hispanic and mainstream prime-time television. J Nutr Educ Behav 2008; 40(6): 348-54. http://dx.doi.org/10.1016/j.jneb.2008.01.003

[8] Henderson VR, Kelly B. Food advertising in the age of obesity: Content analysis of food advertising on general market and African American television. J Nutr Educ Behav 2005; 37(4): 191-96.

\section{http://dx.doi.org/10.1016/S1499-4046(06)60245-5}

[9] Batada A, Seitz MD, Wootan MG, Story M. Nine out of 10 food advertisements shown during Saturday morning children's television programming are for foods high in fat, sodium, or added sugars, or low in nutrients. J Am Diet Assoc 2008; 108(4): 673-78.

http://dx.doi.org/10.1016/j.jada.2008.01.015

[10] Bell RA, Cassady D, Culp J, Alcalay R. Frequency and types of foods advertised on Saturday morning and weekday afternoon English- and Spanish- language American television programs. J Nutr Educ Behav 2009; 41(6): 406-13. http://dx.doi.org/10.1016/i.jneb.2008.05.008

[11] Wilson N, Signal L, Nicholls S, Thomson G. Marketing fat and sugar to children on New Zealand television. Preventive Med 2006; 42(2): 96-101. http://dx.doi.org/10.1016/j.ypmed.2005.11.009

[12] Cheng H, Mueller B, Welfemeyer JT, Rada J. Content of food advertisements on children's television program in China and the United States: A cross-cultural comparison. A paper presented at the American Academy of Advertising 2007 Asia-Pacific Conference, Beijing, May 30 to June 2.

[13] Warren R, Wicks RH, Wicks J, Le Fosu I, Chung D. Food and beverage advertising on U.S. television: A comparison of child-targeted versus general audience commercials. J Broadcast Electr Media 2008; 52(2): 231-46. http://dx.doi.org/10.1080/08838150801992037

[14] Harris JL, Bargh JA, Brownell KD. Priming effects of television food advertising on eating behavior. Health Psychol 2009; 28(4): 404-13.

http://dx.doi.org/10.1037/a0014399
[15] Harrison K, Marske AL. Nutritional content of foods advertised during the television programs children watch most. Am J Public Health 2005; 95(9): 1568-74. http://dx.doi.org/10.2105/AJPH.2004.048058

[16] Kunkel D, Gantz W. Children's television advertising in the multichannel environment. J Commun 1992; 42(3): 134-52. http://dx.doi.org/10.1111/j.1460-2466.1992.tb00803.x

[17] Lewis MK, Hill AJ. Food advertising on British children's television: A content analysis and experimental study with nine-year olds. Int J Obesity 1998; 22(3): 206-14. http://dx.doi.org/10.1038/sj.ijo.0800568

[18] Hasting G, Stead M, McDermott L, Forsyth A, MacKintosh A Bayer $\mathrm{M}$, et al. Review of research on the effects of food promotion to children 2003. Retrieved from http://www. google.com/url?sa=t\&rct=j\&q=\&esrc=s\&source=web\&cd=1\& ved $=0 C C k$ RFAA\&url=http\%3A\%2F\%2Fwww.food.gov.uk\%2 Fmultimedia\%2Fpdfs\%2Ffoodpromotiontochildren1.pdf\&ei=L SEhT-zBDIKuiQermqGkBA\&usg=AFQjCNG2AacQBeiATGsa AGFWjs00jkRL4w

[19] admanGo. Advertising expenditure and ads by product category 2011. Retrieved from http://admanGo.com [subscribed database].

[20] Lee MM, Shen JM. Dietary patterns using traditional Chinese medicine principles in epidemiological studies. Asia Pacific J Clin Nutr 2008; 17(S1): 79-81.

[21] Koo LC. The use of food to treat and prevent disease in Chinese culture. Soc Sci Med 1984; 18(9): 757-66. http://dx.doi.org/10.1016/0277-9536(84)90102-3

[22] Hong Kong Health Food Association. The separation of health food from food 2009. Retrieved from http://www.legco. gov.hk/yr08-09/chinese/panels/fseh/papers/fe0622cb2-19563-c.pdf

[23] Communications Authority. Generic code of practice on television advertising standards 2012. Retrieved from http://www.coms-auth.hk/filemanager/common/policies_ regulations/cop/code_tvad_e.pdf

[24] Centre for Food Safety. Food and drugs (composition and labelling) regulations 2012. Retrieved from http://www.cfs. gov.hk/english/food_leg/food_leg_cl.html\#R4A

[25] admanGo. Advertising expenditure and ads by product category 2012. Retrieved from http://admanGo.com [subscribed database].

[26] Chan K, Tsang L. Promote healthy eating among adolescents: A Hong Kong study. J Consumer Market 2011; 28(5): 354-62.

http://dx.doi.org/10.1108/07363761111150008

\section{DOI: http://dx.doi.org/10.6000/1929-5634.2013.02.03.1}

(C) 2013 Chan et al.; Licensee Lifescience Global.

This is an open access article licensed under the terms of the Creative Commons Attribution Non-Commercial License (http://creativecommons.org/licenses/by-nc/3.0/) which permits unrestricted, non-commercial use, distribution and reproduction in any medium, provided the work is properly cited. 